\title{
Do Political Connections Buffer Firms from or Bind Firms to the Government? A Study of Corporate Charitable Donations of Chinese Firms
}

\author{
Jianjun Zhang \\ Guanghua School of Management, Peking University, Beijing 100871, China, jjzhang@gsm.pku.edu.cn \\ Christopher Marquis \\ Johnson Graduate School of Management, Cornell University, Ithaca, New York 14853, cmarquis@cornell.edu \\ Kunyuan Qiao \\ Mays Business School, Texas A\&M University, College Station, Texas 77843, kqiao@mays.tamu.edu
}

\begin{abstract}
$\mathrm{D}$ o political connections buffer firms from or bind firms to the government? To examine this theoretical puzzle, we distinguish two types of managerial political connections, ascribed and achieved, and theorize that these different types of ties either buffer firms from or bind firms to government demands. Furthermore, we propose that these effects are contingent on both industrial and regional institutional conditions. We test our framework with a unique panel data set of privately controlled listed firms' charitable donations in China from 2001 to 2012. We find that firms whose executives have ascribed bureaucratic connections are more likely to use their connections as a buffer from governmental donation pressure, particularly in competitive industries and less market-oriented regions, whereas in state-monopolized industries this buffering effect is reduced. In contrast, achieved political connections are more likely to serve a binding function that facilitates donation, particularly in state-monopolized industries and more market-oriented regions, but in less marketoriented regions, they buffer firms from the pressure to donate. Our research contributes to the literatures on the effects of political connections, the institutional contingencies of political connections, and the relationship between corporate social responsibility (CSR) and corporate political activities (CPA).
\end{abstract}

Keywords: political connections; corporate charitable donation; resource dependence; institutional environment History: Published online in Articles in Advance September 29, 2016.

\section{Introduction}

As institutional linkages that span firms and governmental authorities, firms' political connections are a key component of corporate political strategy in both developed and emerging economies (Hillman 2005, Hillman et al. 1999, Peng and Luo 2000). However, the effects of political connections on firm behavior and outcomes are not clear (Sun et al. 2012). Many studies focus on the benefits from such linkages and indicate that political connections have a "buffering" effect; that is, they provide a buffer for the organization from competitive and regulatory forces via access to information, influence, and legitimacy (Hillman 2005, Hillman et al. 1999, Lester et al. 2008, Peng and Luo 2000). Research has shown that firms can employ their political capital to shield themselves from unwanted political interference, unfavorable regulations, and/or various forms of government rent expropriation (Mellahi et al. 2016). Even in the United States, political connections have been shown to help firms when they deal with regulators (Correia 2014, Yu and Yu 2011). In emerging markets, such a buffering effect is seen as an effective mechanism to protect firms from government rent-seeking behavior (Chen et al. 2011, Dieleman and Boddewyn 2012).

In contrast, other studies consider these connections from the perspective of the government and emphasize the necessary costs of such linkages for the firm. From this perspective, political connections have a "binding" effect, i.e., they are a mechanism of co-optation, leading firms to be more likely to meet government's requirements (Guthrie and McQuarrie 2008, Marquis and Qian 2014), and correspondingly expose firms to government expropriation (Boubakri et al. 2008, Caprio and Croci 2008). Thus, prior research has shown that organizations with political connections are more likely to pursue social objectives that are encouraged by the government or politicians, and this is due to their concerns about legitimacy (Marquis and Qian 2014), increasing flow of critical resources (Kostka and Zhou 2013), and interest in obtaining the support of critical stakeholders (Wang and Qian 2011).

These contradictory perspectives and empirical findings present an unresolved theoretical puzzle regarding the effects of political ties on business; that is, do firm political ties provide a strategic benefit for firms through 
increased access and influence, or do they result in firms being co-opted, and so lead to them being more likely to conform to government expectations?

We aim to clarify these conflicting findings by developing a more nuanced conceptualization of different types of political ties and the contingencies that affect whether these different types of political ties will be more or less likely to provide buffering or binding effects. We identify and define two types of political ties. First is business executives' prior government working experience. We define these ties as ascribed bureaucratic connections because they represent background characteristics the individual executive obtained before entering business. Second is prestigious appointment to state organs such as congresses or political councils, which we define as achieved political connections, as the formation of these political ties result from executives' or their firms' achievements. Our study identifies how these different types of connections indicate different business-government relationships and theorizes why they have different effects on firm behavior.

Furthermore, we consider how the effects of these types of connections are differentially affected by the firm's resource dependencies such as the level of state monopoly in the firm's industry and the quality of market development in the firm's locality. Since firms face different institutional situations across industries and regions in terms of the degree of resource dependence upon the government, government intervention, property rights protection, and contract enforcement effectiveness (Li et al. 2008, Ma et al. 2013), they might also use their political connections for different purposes across industries and regions. Our basic argument is that the level of resource dependence of the focal firm upon the government, in combination with the nature of political connections, determines whether political connections buffer the firm from, or bind the firm to, the government.

To test our theory and hypotheses, we investigate the relationship between political connections and corporate charitable donations for privately controlled firms (as opposed to state-owned enterprises (SOEs)) in China. This is an excellent context to examine the effects of different types of political ties on firm behavior as the government is an important initiator, stakeholder, and audience of corporate charitable donations (Wang and Qian 2011). On the one hand, political connections might buffer firms against making donations since political connections confer power on the firm, which may protect firms from government expropriation. On the other hand, political connections might also bind firms to the government, since political connections may create obligation and higher government expectations (Marquis and Qian 2014) such that firms may feel especially obliged to donate. Privately controlled firms are particularly attuned to building political connections, considering their need for resources, political protection, and legitimacy (Peng and Luo 2000, Xin and Pearce 1996). Furthermore, the underlying incentives driving privately controlled firm donations are very different from those of SOEs, given SOEs' intrinsic duty to take care of social welfare and managerial agency problems (Shleifer and Vishny 1994). Our sample includes all such firms listed on both the Shanghai and Shenzhen stock exchanges from 2001 to 2012.

We offer three contributions to the literature. First, we theoretically and empirically differentiate between two types of political ties-ascribed versus achieved-and show that this distinction affects whether political ties primarily serve a buffering or binding function. Unpacking the heterogeneity of political ties (Sun et al. 2015, Zheng et al. 2015) is important to better understand the underlying nature and function of such connections and so clarify the aforementioned theoretical puzzle. Second, we identify institutional contingencies that affect firms' resource dependence under which political connections are used strategically as a buffering or binding force. While existing literature focuses on either industry (e.g., DiMaggio and Powell 1983) or region (e.g., Marquis and Battilana 2009), we differentiate and compare the moderating effects of the two. Third, we address the relationship (and potential integration) between corporate social responsibility (CSR) and corporate political activity (CPA) - two important nonmarket strategies (Sun et al. 2012, Mellahi et al. 2016, Werner 2015). We show that, depending on different types of political connections and institutional conditions, CSR and CPA are either complements or substitutes.

\section{Institutional Characteristics and the Nature of Donation in China}

Over the past three decades, China has undergone a fundamental and comprehensive set of institutional changes. Before 1978, China instituted a planned economy in which the state played the central role in resource allocation and industrial operations. During this period, the communist ethos and state control of resources prevented accumulation of private wealth, and examples of Western philanthropic traditions, including volunteering and wealthy individuals acting as philanthropists, were virtually unknown (McGinnis et al. 2009). After 1978, China adopted elements of a market economy, increasing the role of the market in allocating resources while retaining state control of many crucial aspects of the economy. Thus, a "hybrid" or "mixed" economy developed, whereby both the market and the state simultaneously influence firm behavior (Fligstein and Zhang 2011). In the most recent period, while the market has played an increasing role in allocating resources and shaping firm operations (Fan et al. 2011), the government is still a key stakeholder driving a number of business strategies in China, particularly in regard to 
firms' social responsibilities (Marquis and Qian 2014). Thus, prior research has shown that managerial political connections are a key lever through which the government can shape corporate charitable donations (Ma and Parish 2006).

Two prominent institutional characteristics affect the relationship between political connections and corporate charitable donation in China. First, the government is a critical source of resources and legitimacy in China. Since governments at various levels still maintain the power to allocate key resources, issue licenses and permits (for business entry), ratify projects, grant subsidies, allow tax arrears, and provide access to infrastructure (Shi et al. 2014), political connections with the government are of particular importance for business survival and success (Li and Zhang 2007, Peng and Luo 2000). Government control of resources also makes it possible for the government to co-opt businesses/elites by granting resources and legitimacy in exchange for conformity. Accordingly, corporate executives strive to maintain goodwill with the government-including through making charitable donations (Ma and Parish 2006). Meanwhile, the government also seeks to co-opt business leaders as a means of maintaining control of the economy and society (Dickson 2003). For example, the Chinese government has sought to incorporate corporate elites (particularly successful entrepreneurs of privately controlled enterprises) into the political system by appointing them as delegates to the People's Congress (PC; China's legislative body) or to the Chinese People's Political Consultative Conference (CPPCC; China's political consultative body) (Dickson 2003). The political appointments better enable the corporate elites to communicate and negotiate with the government on important policies affecting their business such as entry permit, tax benefits, preferential financing, etc. (Dickson 2003, Li et al. 2008, Wu et al. 2012). In exchange, the government might expect these incorporated business elites and their firms to share responsibilities with the government, such as making donations in the name of the public good (Wang and Qian 2011).

Second, the Chinese government frequently exhibits a strong "grabbing" hand alongside a "helping" hand (Shleifer and Vishny 1994) because of the lack of checks and balances in the political system, poor legal infrastructure, absence of a free press, and nontransparent government decision making (Boisot and Child 1996, Hoskisson et al. 2000). While market reform unleashed forces for economic growth, it also created various problems such as widening the gap between the rich and poor, worsening labor relations, and deteriorating environmental conditions. Because of the increasing social tension, the central government under the $\mathrm{Hu}$ Jintao administration (2002-2012) adopted the socioeconomic ideology of building a "harmonious society" which provided a legitimate rationale for the government and government-organized "nongovernmental organizations" (GONGOs) to pressure firms for donations. Furthermore, considering that China has decentralized the state bureaucracy, fiscal difficulties and social service gaps exist in many places (West and Wong 1995), corporations are increasingly called on to shoulder responsibility with the government.

In addition, unlike in Western countries, where independent NGOs are a key pillar of civil society (Clemens and Guthrie 2010) and social services are increasingly undertaken by NGOs and even businesses, in China, the government imposes tight restrictions on the establishment and operation of NGOs. Purely private and independent NGOs face tremendous hurdles to set up and operate. As a result, existing NGOs are mostly government organized (Foster 2001), either organizations that were previously government agencies or were specifically set up by governmental authorities. For example, the most prominent NGOs in the field of charity, such as China Charity, the Red Cross Society of China, and the China Soong Ching Ling Foundation, are all established and controlled by the government. With their official background and governmental backing, these NGOs often have the power to solicit donations from business organizations. We obtained data from the China Charity report published by the China Charity Information Centre (2007-2014) and summarized the findings in Figure 1 . The figure shows that more than $90 \%$ of donations go to charity institutes with a government background. ${ }^{1}$

Widespread instances of apportionment, imposition, and extortion by government or GONGOs have been well documented in the media. ${ }^{2}$ Hence, "charity apportion" or "forced donation" has become a well-known phenomenon in China. ${ }^{3}$ For example, an investigative report documented the processes of forced donation by the government of Shenmu County in Shanxi Province (Wang 2011). When the Shenmu government set up

\section{Figure 1 Percentage of Donations to Government Affiliated Charities}

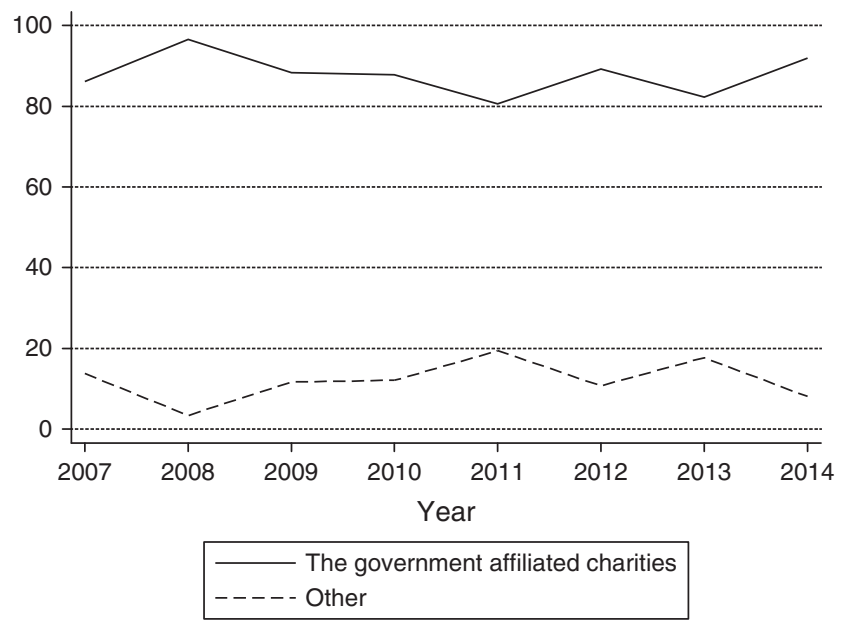

Source. China Charity report. 
three foundations to take care of social welfare and foster sustainable development in 2011, instead of relying on public financing or voluntary contributions, an RMB 3 billion target was assigned and donations were imposed on every firm and public employee in the county. Thus, as prior research has shown, in China, the government is an important initiator, stakeholder, and audience of social responsibility activities such as corporate charitable donation (Marquis and Qian 2014).

\section{Political Connections, Institutions, and Donation}

The extensive literature on corporate political connections demonstrates that firms are strategic in managing their relationships with the government to achieve competitive advantage (Hillman et al. 2004, Schuler et al. 2002). We advance two specific areas within this broad research domain. First, we differentiate different types of political connections-ascribed and achieved and examine their functions. Second, we identify institutional conditions under which political connections buffer firms from or bind firms to the government. The theory we develop below contains the following two insights: on the one hand, the two types of political connections serve different functions, either buffering or binding; on the other hand, such functions can be strengthened, weakened, or even shifted depending on the firms' institutional conditions.

\section{Ascribed and Achieved Political Connections}

To assess and reconcile the seemingly contradictory roles of political connections on corporate charitable donation, we distinguish two types of political connections-ascribed bureaucratic connections and achieved political connections. While the concepts of ascribed versus achieved were developed in sociology (Linton 1936, Stark 2007), we use these two terms to indicate strikingly different types of political connections.

Ascribed bureaucratic connections refer to political ties that executives built as government officials before they entered the business world (similar to ex-politicians in Hillman's 2005 research). In sociology, ascribed attributes of an actor result from background conditions or an individual's history such as family origins. In our context, bureaucratic connections were accumulated during executives' earlier careers as full-time government employees or officials before they became business executives. Previous government working experience endows them with unique information about government bureaucracy and operation (Hillman 2005), a channel of communication and access to existing local government leaders due to their common language, shared experience, and collegial/networked relationships. Since this type of political connection was typically cultivated over a relatively long time period and constitutes an important component of these individuals' careers, it often embodies trust and interpersonal loyalty (with government officials) and is thus relatively stable, so can effectively protect their firm's interests. As former government "insiders," such experiences often indicate deep political embeddedness.

Achieved political connections, on the other hand, result from efforts and achievements from executives' current roles and obligations; in our context, they are defined as political appointments to prestigious state organs acquired after executives became successful business leaders. Achieved political connections are largely a result of ongoing cooperation and favor exchange between business and the government, i.e., resulting from corporate political activities (CPAs) and efforts and the government's interest in co-opting business leaders. As political "outsiders," these executives gain political connections through efforts/achievements. Only when firms become large and executives become successful is it possible for these executives to be appointed to these political bodies. For instance, Dickson (2003) finds that Chinese government rewarded the entrepreneurs of private enterprises via political appointments. Given term limits, ${ }^{4}$ political ties via such appointments often last for a shorter period.

We theorize that these two types of connections differ in how and when they are accumulated and reflect different business-government relationships, and so it is reasonable to expect that they have different impacts on firm behavior. As social capital in stock, ascribed bureaucratic connections create a "detaching effect," allowing firms to distance themselves from the government while protecting their interests. Those former government officials do not have any formal obligation to shoulder responsibilities with the government. Furthermore, their network with government leaders will effectively protect them from rent expropriation.

Achieved political connections are earned by firms'/ executives' efforts to meet government expectations, or the government identifies them as important to co-opt, thus creating a strong "attaching effect" between firms and the government. Firms' compliance or active alignment with government expectations further advances and protects their interests as well as consolidates their executives' political status. Therefore, we generally expect that executives with achieved political connections are more likely to meet government expectations. Table 1 summarizes the differences of the two types of political connections.

Ascribed Bureaucratic Connections and Corporate Charitable Donation. The ascribed bureaucratic connections bring resources and leverage, which are likely to buffer firms from external claims and impositions including donations. First, such connections provide 
Table 1 Comparisons of the Two Types of Political Connections

\begin{tabular}{|c|c|c|}
\hline & Ascribed bureaucratic connections & Achieved political connections \\
\hline Definition & $\begin{array}{l}\text { Based on actors' background } \\
\text { characteristics }\end{array}$ & Reflecting or a result of actors' current position \\
\hline Expression in China & $\begin{array}{l}\text { Former government officials before taking } \\
\text { current position }\end{array}$ & $\begin{array}{l}\text { Appointment to political body or council after achieving } \\
\text { current position }\end{array}$ \\
\hline Tie cultivation mechanisms & $\begin{array}{l}\text { Deep political embeddedness; political } \\
\text { insiders now working outside the } \\
\text { government }\end{array}$ & $\begin{array}{l}\text { Result of CPA, transaction/exchange between business and } \\
\text { government; political outsiders now with a position inside } \\
\text { the government }\end{array}$ \\
\hline Functions & Knowledge, skill, network & Political recognition, network, responsibility \\
\hline Pressures & $\begin{array}{l}\text { Detaching effect; no government/social } \\
\text { expectation }\end{array}$ & $\begin{array}{l}\text { Attaching effect; expected to shoulder obligations and } \\
\text { duties }\end{array}$ \\
\hline Outcome & Buffering & Binding, co-optation \\
\hline
\end{tabular}

unique information and knowledge about bureaucratic operation, which, because of its complexity, is often very expensive or difficult for a firm to obtain (Hillman et al. 1999). For instance, such knowledge in China enables firms to differentiate various GONGOs and government requests, complying with serious requests while ignoring less consequential ones. Second, their network provides a channel of communication or access to existing politicians and bureaucrats, which can protect firms from excess imposition and potential sanction as well. Third, their experience and skill also help them deal with government agencies/officials more successfully, and avoid offending the government even if they do not donate. For the government and GONGOs, firms without political connections are also more likely to become "soft targets" of imposition, since they have the weakest incentives and ability to resist external demands (Baron et al. 2011). These arguments particularly apply to privately controlled firms in China. As a relatively new organizational form in China's emerging market, privately controlled firms are vulnerable to various claims and impositions, and are often subject to arbitrary harassment from the government (Li et al. 2008). Executives with political connections, however, may mitigate or even overcome this disadvantage (Xin and Pearce 1996). Therefore:

Hypothesis 1 (H1). Firms with executives who have ascribed bureaucratic connections are less likely to donate compared to firms whose executives do not have such connections.

Achieved Political Connections and Corporate Charitable Donation. There is some rationale suggesting that achieved political connections might also serve as a buffer from governmental pressure, providing political clout that may allow firms to fend off external claims. And executives who lack political connections may be more active in making donations to create goodwill with the government, with the purpose of cultivating political connections (Ma and Parish 2006). While these arguments may apply under some conditions that we elaborate below, we argue that on average, achieved political connections are more likely to bind firms to the government and thus facilitate donation.

First, achieved political connections indicate more of an ongoing exchange relationship between business elites (and their organizations) and the government, whereby the government provides the political recognition, social status, and prestige, and as a response, firms are likely to be motivated to take the lead in social contributions out of both positive duty and negative duty (Swanson 1999). In terms of positive duty, executives with achieved political connections might have better understanding and greater information about the government concern as well as higher awareness of corporate social responsibility, and thus are more likely to adopt the government's perspective and be committed to donating for societal wellbeing. In addition, based on the Confucian social model of role transition (i.e., the individuals should transition from self-orientation to social-orientation after they succeed), prior research has suggested that successful entrepreneurs are more likely to be motivated by prosocial concerns ( $\mathrm{Li}$ and Liang 2015). In terms of negative duty, achieved political connections generate higher expectations by the government and the general public, and thus firms are pressured to take greater initiative in social welfare to be consistent with their political status (Marquis and Qian 2014). Finally, the fear of losing political appointments also binds firms to government demands, because such political status could be vulnerable to competition from executives without political connections who desire such positions.

Hypothesis 2 (H2). Firms with executives who have achieved political connections are more likely to donate compared to firms whose executives do not have such connections.

\section{Resource Dependence and Effects of Political Connections}

We further argue that whether political connections will buffer or bind firms is also affected by the level of resource dependence of firms upon the government 
(Oliver 1991, Pfeffer and Salancik 1978). Given that the level of resource dependence of firms on the government is contingent upon the institutional environment in which they operate, we posit that the effects of political connections on corporate charitable donations vary across different institutional settings, following the argument that the institutional environment shapes firm strategy (e.g., Kozhikode and Li 2012, Marquis and Raynard 2015).

The institutional arrangement of industry in China determines the extent to which entry to the industry and access to critical resources is controlled by the government. With the legacy of a planned economy, government intervention in China is mainly exemplified by industry regulation (Ortega et al. 2011). For example, the government controls licenses and permits for access to critical industries including finance, energy, utilities, transportation, and certain heavy industries in the name of national interest (Eaton 2013). Without government permission, privately controlled firms cannot enter such industries (Gallagher 2006). Moreover, the government is deeply involved in many industry-specific regulations (e.g., Gallagher 2006) and can intervene via discriminating policies such as preferential tax, financing, etc. (Wu et al. 2012). Industry hence constitutes a firm's task environment (Thompson 1967), which is critical for firm survival and success.

In contrast, regional market characteristics are more indicative of the quality of the general institutional infrastructure, such as government service/intervention, legal protection of property rights, contractual enforcements, and other related factors (Fan et al. 2011, Ma et al. 2013), since legal apparatuses are influenced by local governments in China instead of standing as independent entities (Ginsburg and Moustafa 2008). The resource dependence of the firm on regional institutional environment is comparatively less severe than that on industry. For instance, business entry/permits in certain industries are vital for firms, while firms can choose to go to court or to circumvent lawsuits ${ }^{5}$ depending upon the effectiveness of the legal apparatus in a region (Firth et al. 2011). In general, if industry environment determines life and death for the firm, then regional environment influences the quality of the firm's life.

Level of State Monopoly of Industry and the Effect of Political Connections. The extent to which a privately controlled firm uses political connections to buffer or bind differs across industries. As Baron (1995) suggests, the importance of a firm's political strategy is positively associated with the degree of government control over the opportunities in the industry where the firm resides. Thus, firms relying more on the government and firms in regulated industries have been shown to be more active in political activities and are more likely to combine various political activities (Agrawal and Knoeber 2001, Hillman 2005, Peng and Luo 2000, Schuler et al. 2002).
Brown et al. (2006) find that firms in more regulated industries are more likely to make charitable contributions to garner government goodwill. Active CSR is also used to gain legitimacy in some industries such as the Tobacco industry (Palazzo and Richter 2005).

The above rationale is applicable to the relationship between political connections and corporate charitable donation in state-monopolized industries in China. Firms in state-monopolized industries are more dependent on the government for license approval/renewal, access to government-controlled resources and preferential treatment, and subject to frequent government intervention (Eaton 2013). Resource dependence upon the government makes firms more likely to comply with government/GONGO demands or even proactively to engage in donation to gain government goodwill (Pfeffer and Salancik 1978). Meanwhile, since state-monopolized industries are politically salient and attract more government attention, and privately controlled firms in such industries also have a stronger need to gain legitimacy and improve their image, they can not risk defying government demands. To keep the status quo or seek greater advantage (Boddewyn and Brewer 1994), firms with political connections-both ascribed and achievedhave incentives to continuously maintain or further improve their relationship with the government. Consequently, the buffering effect of ascribed bureaucratic connections would be weaker and the binding effect of achieved political connections would be stronger in state-monopolized industries.

Furthermore, in state-monopolized industries, firms with political connections would have better understanding of government concerns (e.g., identifying significant social and political issues) and gain more benefits by aligning with government expectations. Therefore, existing political connections might serve as channel and bridge through which firms build further linkages by making donations, strengthening their competitive advantage as well as hindering their rivals in the industry (Delmas et al. 2016, McWilliams et al. 2002). In contrast, highly competitive industries are more open to market competition and less controlled by the government. Firms in such industries are more conscious of committing resources to the market rather than catering to the government to survive competition (Davies and Walters 2004). As a result, we expect the following:

Hypothesis 3A (H3A). The buffering effect of executives' ascribed bureaucratic connections against donation pressure is weaker for firms in state-monopolized industries than those in competitive industries.

Hypothesis 3B (H3B). The binding effect of executives' achieved political connections that lead them to donate is stronger for firms in state-monopolized industries than those in competitive industries. 
Quality of Regional Market Development and the Effect of Political Connections. Regional institutional differences are mainly exemplified by the quality of market development of the regions where firms are located. More market-oriented regions have a higher quality of market development and better legal infrastructure such as protection of property rights and contract enforcement, while less market-oriented regions usually are characterized by a higher degree of government intervention, administrative harassment, and poorer legal infrastructure (Li et al. 2008, Zhou and Poppo 2010). Based on the same logic presented above on how industry moderates the effect of political ties, it is reasonable to expect that political connections would be more likely to bind firms to the government in less market-oriented regions (as in more state-monopolized industries), since firms rely more on the government and thus cannot afford the cost of defying government demands in these regions.

However, because of the different nature of institutional pressure associated with region relative to industry (Marquis and Battilana 2009, Oliver 1991), we argue that in less market-oriented regions, both types of political connections are more likely to serve as a buffer against external impositions. First, the regional institutional environment creates a lower degree of resource dependence of the focal firm upon the government relative to industry, which increases the likelihood of organizational resistance (Oliver 1991). Thus, political connections in less market-oriented regions may be used to defend firm interests by resisting government expropriation, effectively mitigating the binding function of political connections in these regions. Second, the regional environment consists of multiple, complex, and fragmented constituents (e.g., various government bureaus might have different interests), which also creates room for organizational resistance (Pfeffer and Salancik 1978, p. 27). Comparatively, industry regulation is more focused and concentrated in China. Third, the degree of interconnectedness of actors differs between the two institutions. While there is typically higher interconnectedness of actors in the industry environment (as a legacy of China's planned economy and focus of industry regulation), actors in regional institutional environment are more loosely connected, which further alleviates the risk of organizational resistance; that is, the nature of institutional pressures associated with region makes organizational resistance feasible.

As a result, in less market-oriented regions, firms are likely to use political connections to defy government demands. The stronger the grabbing hand of the government, the more likely the firm is motivated to cultivate political connections to prevent rent seeking. In places where market institutions are less developed, political connections are likely to be used to protect firm interests (Xin and Pearce 1996, Zhou and Poppo 2010), including but not limited to defying rent expropriation. Therefore,
Hypothesis 4A (H4A). The buffering effect of executives' ascribed bureaucratic connections against donation pressure is stronger for firms in less marketoriented regions than those in more market-oriented regions.

Hypothesis 4B (H4B). The binding effect of executives' achieved political connections that lead them to donate is weaker for firms in less market-oriented regions than those in more market-oriented regions.

\section{Methods}

\section{Data and Sample}

Our sample consists of all privately controlled firms listed on both Shanghai and Shenzhen stock exchanges from 2001 to 2012. Our data set was drawn from several data sources including the China Stock Market and Accounting Research (CSMAR) database, company annual reports, and company websites. The CSMAR and Sinofin databases are widely used in studies on China's listed companies, and they provide credible information about companies' background and financial statistics (e.g., Wang and Qian 2011). After deleting 123 observations of 15 firms with missing values, the final sample consists of 820 firms and 5,803 firm-year observations.

Donation information is available in the CSMAR database from 2001 to 2006 . We extended such information to 2012 by collecting donation data directly from the "notes to financial reports" (termed as "corporate (charitable) donations") in company annual reports. Executives' political connections and functional background were collected manually from brief biographical descriptions of the firms' top executives provided by CSMAR, company websites, and some professional financial news sites (e.g., Sina Finance). If information was still unavailable, we searched for the firm and the executive's name as the keywords in Baidu - the most commonly used search engine in China-and collected the information accordingly.

\section{Dependent Variables}

We examined both the likelihood and amount of donation that a firm made in a certain year between 2001 and 2012. (i) The likelihood of donation is coded 1 for firms that donated in a given year ("donor") and 0 for those that did not donate, and (ii) we took the logarithm of the total donation for cases with positive amount of donation (amount of donation), leaving those cases with no donation as 0 . Among firms that donated, the average donation amount is approximately $¥ 1,291,410$ (US $\$ 174,988$, based on the 2007 exchange rate), accounting for $1.7 \%$ of the firms' profit and 5.2\% of the firms' cash flow.

\section{Independent Variables}

We distinguished between ascribed bureaucratic connections and achieved political connections of the 
chairperson of the company's board of directors. In China the most powerful executive position in the firm is the board chair (Li and Liang 2015). The Company Law in China stipulates that the chair is the legal representative of the company and is accountable for important company decisions.

Ascribed bureaucratic connection was measured by whether the chair had only government working experience before serving as the chair. For privately controlled firms, such a stint usually occurred before the chair joined the company. This measure is widely used and well established in the existing literature to capture the political connection (e.g., Faccio 2006, Fan et al. 2007).

Achieved political connection was measured by whether a firm's chair was only serving as a delegate to People's Congress or Chinese People's Political Consultative Conference. While these bodies exist at five different hierarchical levels from township to national, given the elite status of executives in Chinese publicly listed firms, we only considered the higher prestige, national- and provincial-level PC/CPPCC. The results remain similar when including other levels of PC/CPPCC membership.

\section{Moderators}

Level of State Monopoly of Industry. Based on wellestablished calculations of state monopoly across industries in China (e.g., Jin 2005, Song et al. 2011), we calculated the degree of state monopoly by computing the proportion of SOEs' sales to those of the total industry (at three-digit level) for each year. A higher score indicates a higher level of state monopoly, i.e., there is stronger state control of those industries. Examples of highly state-monopolized industries are electricity, finance, telecommunications, and petroleum.

Quality of Regional Market Development. We capture the quality of market development of the firm's headquarters province using the well-established provincial marketization indices developed by the National Economic Research Institute (Fan et al. 2011). We reverse coded this variable by subtracting the value of marketization index for each province from 12, which is the maximum possible value, to keep the direction of the measure consistent with our hypotheses. A higher value indicates a lower quality of regional market development. Since the most recently available indices were updated to 2009, and the relative degrees of marketization of provinces are stable over the years, we used the 2009 values for 2010 to 2012. Results are unchanged if we restrict the sample to the 2001 to 2009 data.

\section{Control Variables}

We controlled for a wide range of characteristics of the firm, its leader, and its industry. A number of firm characteristics may affect the likelihood and amount of donation. We included firm size, which was measured as the logarithm of revenue (Grant et al. 1988), since politics are more important to larger and more visible firms (Agrawal and Knoeber 2001). Prior research suggests that ownership concentration allows owners to monitor effectively and thus to discourage management from making donations (Brown et al. 2006). We controlled for ownership concentration by the percentage of shares owned by the five largest shareholders. We employed the number of years since the firm's initial public offering $(I P O)$ to control for the influence of firm exposure to stock market. Furthermore, we used return on assets (ROA) to measure firm performance (Wang and Qian 2011). We lagged firm performance by one year to avoid endogeneity arising from reverse causation. We also controlled for slack resources, measured as cash flow over total assets (Wang and Qian 2011). Additionally, we calculated sales expenditure over revenue to measure advertising intensity since research suggests that firms that emphasize sales and marketing are more image conscious and so more likely to donate (e.g., Navarro 1988). To avoid undue influence from outliers, we winsorized variables ROA and sales expenditures over revenues at the $1 \%$ level.

We controlled for characteristics of a firm's chair, since different leadership characteristics might affect firm donation (Chin et al. 2013, Li and Liang 2015). Such characteristics include (1) chairs with both political connections, which helps to rule out any conflicting effects of two different types of political connections; (2) age, measured in year; (3) gender, which equals 1 if a chair is male; (4) educational attainment, which is coded as 6 for doctorate degree, 5 for master's degree, 4 for undergraduate degree, 3 for high school, 2 for middle school, 1 for primary school, and 0 for those below primary school (Thomas et al. 1991); and (5) tenure, measured by the years in the position. We also used duality of chair and CEO to measure whether the position of chair and chief executive officer (CEO) were held by the same person, to proxy executive power (Sauerwald et al. 2016). In addition, top executives with different functional backgrounds have different strategic priorities (e.g., Hambrick and Mason 1984), and those with sales or marketing background may develop a different strategic perception of charitable giving. We coded chair has sales/marketing background using the position and department affiliation of the executive's longest working experience (Thomas et al. 1991).

Studies on practice diffusion find that a practice adopted by socially proximate firms (for example, those in the same industry) will be more quickly adopted by the focal firm (e.g., Davis and Greve 1997). We thus controlled for the influence of three-digit level industry average donation, i.e., average donation likelihood of firms in industry and average donation amount of firms in industry for the likelihood and amount of donation 
each year. Last, we included year dummies to capture time period variation.

\section{Estimation Methods}

Since the likelihood of donation (donor) is a binary variable, a probit model is appropriate. ${ }^{6}$ It is not possible to use fixed effects in probit models due to the "incidental parameter problem" (i.e., there are too many parameters to be estimated), so we employed probit models with random effects estimation to account for the heterogeneity of each firm (Lancaster 2000). We conducted a number of tests and robustness checks to verify that our random effects probit model returned valid results. First, we performed a Hausman test to compare the results from a Logistic model with both fixed and random effects estimations and found that there were no systematic differences and thus random effects estimation is appropriate (Hausman 1978). In addition, we conducted the Breusch-Pagan test (Breusch and Pagan 1979) to compare the results from random effects and pooled estimation and found that the pooled estimation would not deliver consistent results.

Our second dependent variable, the amount of donation, is contingent upon the decision to donate, and this introduces selection bias if we use a linear model to estimate the amount of donation directly. We thus adopted the two-step Heckman selection model, where the first step is likelihood of donation as described above, and the second step is then amount of donation based on those that have donated and controls for the inverse Mill's ratio from the first step (Wang and Qian 2011).

More importantly, considering that firms may choose executives with political connections, the key variables in our study-political connections - maybe endogenous. To address this issue, we used the propensity score matching (PSM) method, which is commonly used in management research on firms' social networks (Choi et al. 2014, Haveman et al. 2016). Propensity score matching alleviates endogeneity concerns by matching firms receiving treatment (obtaining political connection) or not on the observable variables, and thus eliminating spurious results caused by these variables (Dehejia and Wahba 2002, Rosenbaum and Rubin 1983). Using a multinomial logistic model, we predicted the likelihood of selection into treatments (ascribed, achieved, and both; those without any political connections serve as the control) ${ }^{7}$ with all the observable exogenous (control) variables. PSM computes the propensity score for each observation, i.e., the predicted probability of acquiring political connection or not and of what type, and based on this score a matched sample of firms with and without political connections is formed. ${ }^{8}$ The finally matched sample contains more than $65 \%$ of the original observations, among which $64 \%$ of the firms donated, comparable to the original sample. We conducted a wide range of tests to assure matching quality. Tests indicate that (a) the differences in the variables between treated and control groups are not statistically significant at the 5\% level, the accepted threshold (Rosenbaum and Rubin 1983 ), and (b) the pseudo- $R^{2}$ of multinomial logistic regression after the matching was extremely small (0.0001), both of which suggest good matching quality and that the covariates are balanced well. For details of the matching quality tests, see Table A1 in Online Appendix A (available as supplemental material at http:// dx.doi.org/10.1287/orsc.2016.1084). With the matched sample, we implemented the two-step Heckman selection model for the likelihood and amount of donation as described above.

\section{Results}

Descriptive statistics and the correlation matrix are presented in Table 2. We can see that the correlation coefficients between the explanatory variables are relatively small with the largest one being -0.476 (percentage of shares owned by the five largest shareholders and years since listed). We checked variance inflation factors (VIFs) and found that the highest VIF among those in our model was 2.828 , well below the general cutoff 10; therefore multicollinearity does not pose a serious concern. Overall, $60 \%$ of sampled firm/years donated between 2001 and 2012, 12.7\% of chairpersons have ascribed bureaucratic connections, and $23.7 \%$ have achieved political connections, while $3.4 \%$ have both.

Table 3 presents the results from the multiple regression models: models 1-3 present the results of the first step results of the two-step Heckman selection model, i.e., the probit model with random effects for the likelihood of donation; models 4-6 present the results of the second step results of the two-step Heckman selection model, i.e., the fixed effects linear model for the amount of donation by controlling for the inverse Mill's ratio calculated from the first step.

Hypothesis 1 posits the buffering effect of ascribed bureaucratic connections. The results from both model 3 and model 6 provide strong and consistent support for our hypothesis: firms whose chairpersons have government working experience are less likely to donate $(\beta=-0.532, p<0.01)$, and the amount of donation of these firms is also smaller than that of firms without such political connections $(\beta=-3.737, p<0.01)$. Hypothesis 1 is supported.

Hypothesis 2 argues for the binding effect of achieved political connections on donation. The results show that firms whose chairpersons have achieved political connections are more likely to donate $(\beta=0.927, p<0.01)$ and in greater amount $(\beta=4.984, p<0.01)$. Hypothesis 2 is supported. Thus, our empirical results reveal the different impacts (and functions) of two types of political connections upon firm donation.

Hypotheses $3 \mathrm{~A}$ and $3 \mathrm{~B}$ propose the moderating role of level of state monopoly of industry on the relationship 


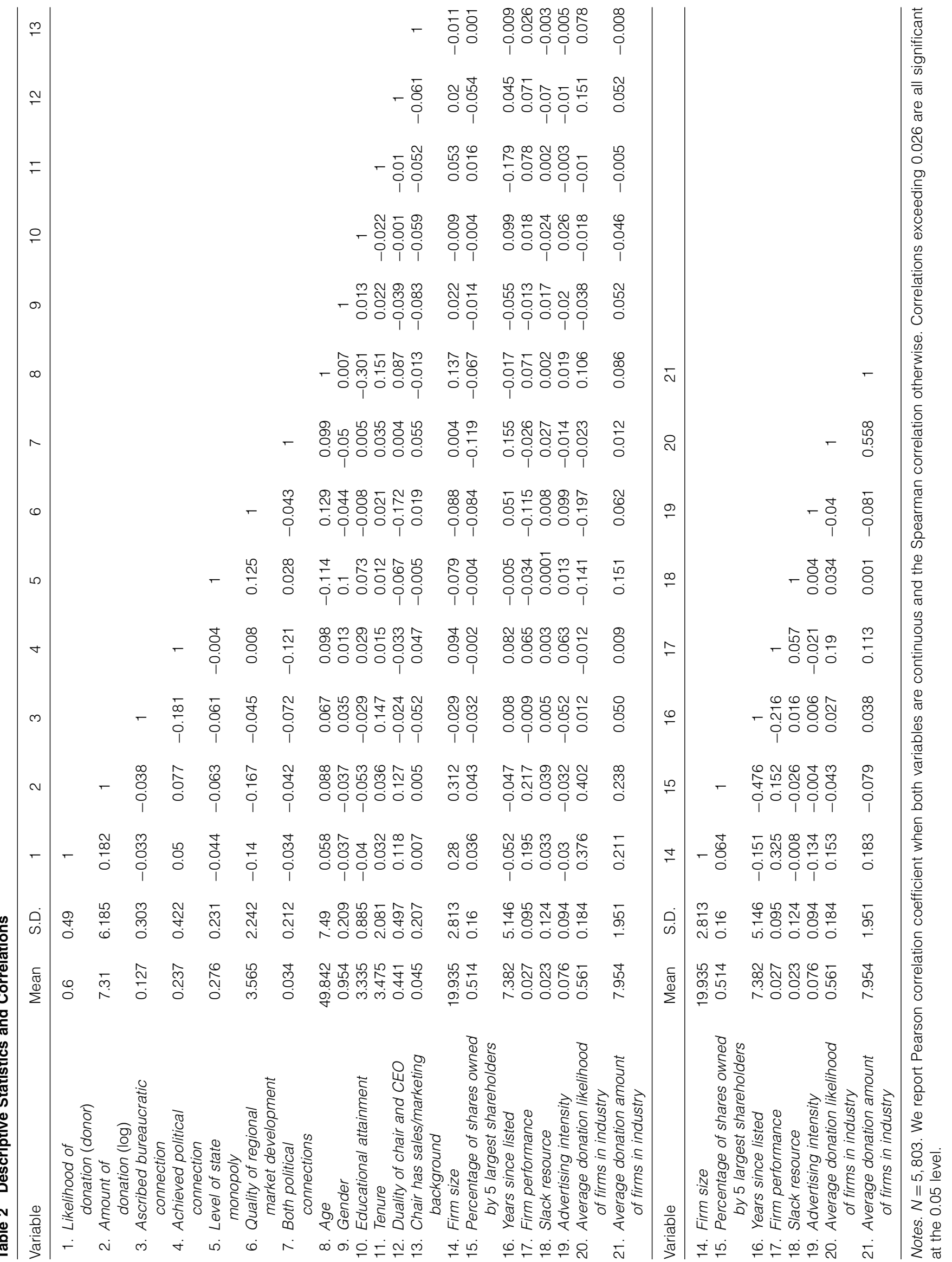


Zhang, Marquis, and Qiao: A Study of Corporate Charitable Donations of Chinese Firms

Organization Science 27(5), pp. 1307-1324, (C) 2016 INFORMS

Table 3 Determinants of the Likelihood and Amount of Donation by Propensity Score Matching

\begin{tabular}{|c|c|c|c|c|c|c|}
\hline \multirow{2}{*}{$\frac{\text { Model }}{\text { Dependent variable }}$} & 1 & 2 & 3 & 4 & 5 & 6 \\
\hline & \multicolumn{3}{|c|}{ Donor } & \multicolumn{3}{|c|}{ Amount of donation } \\
\hline Both political connections & $\begin{array}{l}-0.018 \\
(0.284)\end{array}$ & $\begin{array}{r}-0.013 \\
(0.292)\end{array}$ & $\begin{array}{c}-0.012 \\
(0.291)\end{array}$ & $\begin{array}{r}-0.068 \\
(0.073)\end{array}$ & $\begin{array}{r}-0.088 \\
(0.078)\end{array}$ & $\begin{array}{r}-0.073 \\
(0.082)\end{array}$ \\
\hline CEO age & $\begin{array}{l}0.021^{* *} \\
(0.007)\end{array}$ & $\begin{array}{l}0.023^{* *} \\
(0.007)\end{array}$ & $\begin{array}{l}0.022^{* *} \\
(0.007)\end{array}$ & $\begin{array}{c}0.002 \\
(0.019)\end{array}$ & $\begin{array}{c}0.004 \\
(0.019)\end{array}$ & $\begin{array}{c}0.004 \\
(0.019)\end{array}$ \\
\hline CEO gender & $\begin{array}{c}-0.084 \\
(0.061)\end{array}$ & $\begin{array}{r}-0.100 \\
(0.062)\end{array}$ & $\begin{array}{l}-0.100 \\
(0.062)\end{array}$ & $\begin{array}{c}-0.181 \\
(0.171)\end{array}$ & $\begin{array}{c}-0.201 \\
(0.171)\end{array}$ & $\begin{array}{r}-0.184 \\
(0.173)\end{array}$ \\
\hline CEO educational attainment & $\begin{array}{c}-0.208 \\
(0.189)\end{array}$ & $\begin{array}{r}-0.190 \\
(0.190)\end{array}$ & $\begin{array}{c}-0.191 \\
(0.189)\end{array}$ & $\begin{array}{r}-0.219 \\
(0.368)\end{array}$ & $\begin{array}{r}-0.179 \\
(0.368)\end{array}$ & $\begin{array}{r}-0.190 \\
(0.369)\end{array}$ \\
\hline CEO tenure & $\begin{array}{l}0.012 \\
(0.026)\end{array}$ & $\begin{array}{c}0.009 \\
(0.026)\end{array}$ & $\begin{array}{l}0.008 \\
(0.026)\end{array}$ & $\begin{array}{l}0.049 \\
(0.105)\end{array}$ & $\begin{array}{l}0.036 \\
(0.106)\end{array}$ & $\begin{array}{c}0.022 \\
(0.107)\end{array}$ \\
\hline Duality of chair and CEO & $\begin{array}{c}0.030 \\
(0.135)\end{array}$ & $\begin{array}{l}0.030 \\
(0.136)\end{array}$ & $\begin{array}{c}0.035 \\
(0.135)\end{array}$ & $\begin{array}{r}0.318^{*} \\
(0.160)\end{array}$ & $\begin{array}{l}0.521^{* *} \\
(0.183)\end{array}$ & $\begin{array}{l}0.508^{* *} \\
(0.184)\end{array}$ \\
\hline $\begin{array}{l}\text { Chair has sales/marketing } \\
\text { background }\end{array}$ & $\begin{array}{c}0.016 \\
(0.221)\end{array}$ & $\begin{array}{l}0.031 \\
(0.221)\end{array}$ & $\begin{array}{c}0.046 \\
(0.220)\end{array}$ & $\begin{array}{r}0.635^{+} \\
(0.356)\end{array}$ & $\begin{array}{r}0.735^{*} \\
(0.357)\end{array}$ & $\begin{array}{r}0.730^{*} \\
(0.358)\end{array}$ \\
\hline Firm size & $\begin{array}{l}0.157^{* *} \\
(0.027)\end{array}$ & $\begin{array}{l}0.151^{* *} \\
(0.027)\end{array}$ & $\begin{array}{l}0.150^{* *} \\
(0.026)\end{array}$ & $\begin{array}{l}0.000 \\
(0.073)\end{array}$ & $\begin{array}{l}0.004 \\
(0.073)\end{array}$ & $\begin{array}{l}0.004 \\
(0.074)\end{array}$ \\
\hline $\begin{array}{c}\text { Percentage of shares owned } \\
\text { by } 5 \text { largest shareholders }\end{array}$ & $\begin{array}{l}0.505 \\
(0.426)\end{array}$ & $\begin{array}{c}0.619 \\
(0.427)\end{array}$ & $\begin{array}{c}0.639 \\
(0.426)\end{array}$ & $\begin{array}{l}0.160 \\
(0.924)\end{array}$ & $\begin{array}{c}0.000 \\
(0.925)\end{array}$ & $\begin{array}{c}0.028 \\
(0.935)\end{array}$ \\
\hline Years since listed & $\begin{array}{c}-0.057^{* *} \\
(0.017)\end{array}$ & $\begin{array}{c}-0.058^{* *} \\
(0.017)\end{array}$ & $\begin{array}{c}-0.061^{* *} \\
(0.017)\end{array}$ & $\begin{array}{r}-0.128^{*} \\
(0.051)\end{array}$ & $\begin{array}{c}-0.293^{* *} \\
(0.099)\end{array}$ & $\begin{array}{c}-0.289^{* *} \\
(0.100)\end{array}$ \\
\hline Firm performance & $\begin{array}{l}1.154^{*} \\
(0.457)\end{array}$ & $\begin{array}{r}1.116^{*} \\
(0.456)\end{array}$ & $\begin{array}{r}1.162^{*} \\
(0.456)\end{array}$ & $\begin{array}{r}1.685^{+} \\
(0.906)\end{array}$ & $\begin{array}{r}1.524^{+} \\
(0.888)\end{array}$ & $\begin{array}{c}1.457 \\
(0.910)\end{array}$ \\
\hline Slack resource & $\begin{array}{c}0.002 \\
(0.003)\end{array}$ & $\begin{array}{c}0.002 \\
(0.003)\end{array}$ & $\begin{array}{c}0.002 \\
(0.004)\end{array}$ & $\begin{array}{l}0.003 \\
(0.004)\end{array}$ & $\begin{array}{c}0.003 \\
(0.004)\end{array}$ & $\begin{array}{c}0.003 \\
(0.005)\end{array}$ \\
\hline Advertising intensity & $\begin{array}{r}-1.031^{*} \\
(0.503)\end{array}$ & $\begin{array}{r}-0.994^{*} \\
(0.440)\end{array}$ & $\begin{array}{r}-0.938^{*} \\
(0.428)\end{array}$ & $\begin{array}{r}-2.152 \\
(2.478)\end{array}$ & $\begin{array}{c}-2.002 \\
(2.482)\end{array}$ & $\begin{array}{r}-1.962 \\
(2.496)\end{array}$ \\
\hline $\begin{array}{l}\text { Average donation likelihood of } \\
\text { firms in industry }\end{array}$ & $\begin{array}{l}4.143^{* *} \\
(0.478)\end{array}$ & $\begin{array}{l}4.205^{* *} \\
(0.481)\end{array}$ & $\begin{array}{l}4.192^{* *} \\
(0.479)\end{array}$ & & & \\
\hline $\begin{array}{l}\text { Average donation amount of } \\
\text { firms in industry }\end{array}$ & & & & $\begin{array}{l}0.471^{* *} \\
(0.073)\end{array}$ & $\begin{array}{l}0.483^{* *} \\
(0.074)\end{array}$ & $\begin{array}{c}0.487^{* *} \\
(0.075)\end{array}$ \\
\hline $\begin{array}{l}\text { Ascribed bureaucratic } \\
\text { connection }(\mathrm{H} 1)\end{array}$ & & $\begin{array}{r}-0.376^{*} \\
(0.178)\end{array}$ & $\begin{array}{c}-0.532^{* *} \\
(0.193)\end{array}$ & & $\begin{array}{r}-1.060^{*} \\
(0.456)\end{array}$ & $\begin{array}{r}-3.737^{* *} \\
(1.144)\end{array}$ \\
\hline Achieved political connection $(\mathrm{H} 2)$ & & $\begin{array}{r}0.357^{*} \\
(0.147)\end{array}$ & $\begin{array}{l}0.927^{* *} \\
(0.313)\end{array}$ & & $\begin{array}{l}1.602^{* *} \\
(0.487)\end{array}$ & $\begin{array}{c}4.984^{* *} \\
(1.642)\end{array}$ \\
\hline Level of state monopoly & & $\begin{array}{r}-0.078^{+} \\
(0.043)\end{array}$ & $\begin{array}{r}-0.120^{*} \\
(0.059)\end{array}$ & & $\begin{array}{r}-1.119^{*} \\
(0.558)\end{array}$ & $\begin{array}{r}-1.239^{+} \\
(0.711)\end{array}$ \\
\hline $\begin{array}{l}\text { Quality of regional } \\
\text { market development (reverse coded) }\end{array}$ & & $\begin{array}{r}-0.059^{*} \\
(0.026)\end{array}$ & $\begin{array}{r}-0.061^{*} \\
(0.028)\end{array}$ & & $\begin{array}{r}-0.517^{*} \\
(0.235)\end{array}$ & $\begin{array}{r}-0.546^{*} \\
(0.243)\end{array}$ \\
\hline $\begin{array}{l}\text { Ascribed bureaucratic connection } \\
\quad \times \text { State monopoly }(\mathrm{H} 3 \mathrm{~A})\end{array}$ & & & $\begin{array}{l}1.785^{* *} \\
(0.598)\end{array}$ & & & $\begin{array}{l}2.763^{* *} \\
(1.003)\end{array}$ \\
\hline $\begin{array}{l}\text { Achieved political connection } \\
\times \text { State monopoly }(\mathrm{H} 3 \mathrm{~B})\end{array}$ & & & $\begin{array}{l}2.242^{* *} \\
(0.837)\end{array}$ & & & $\begin{array}{l}2.093^{* *} \\
(0.718)\end{array}$ \\
\hline $\begin{array}{l}\text { Ascribed bureaucratic connection } \\
\quad \times \text { Quality of regional market development }(\mathrm{H} 4 \mathrm{~A})\end{array}$ & & & $\begin{array}{c}-0.138^{* *} \\
(0.031)\end{array}$ & & & $\begin{array}{c}-0.109^{* *} \\
(0.029)\end{array}$ \\
\hline $\begin{array}{l}\text { Achieved political connection } \\
\quad \times \text { Quality of regional market development }(\mathrm{H} 4 \mathrm{~B})\end{array}$ & & & $\begin{array}{c}-0.103^{* *} \\
(0.028)\end{array}$ & & & $\begin{array}{r}-0.094^{* *} \\
(0.031)\end{array}$ \\
\hline Inverse Mill's ratio & & & & $\begin{array}{c}-0.348 \\
(0.274)\end{array}$ & $\begin{array}{c}-0.265 \\
(0.277)\end{array}$ & $\begin{array}{r}-0.294 \\
(0.281)\end{array}$ \\
\hline Intercept & $\begin{array}{c}-3.716^{* *} \\
(0.767)\end{array}$ & $\begin{array}{c}-3.893^{* *} \\
(0.798)\end{array}$ & $\begin{array}{c}-3.578^{* *} \\
(0.814)\end{array}$ & $\begin{array}{c}6.989^{* *} \\
(2.169)\end{array}$ & $\begin{array}{l}11.413^{* *} \\
(2.750)\end{array}$ & $\begin{array}{l}11.267^{* *} \\
(2.870)\end{array}$ \\
\hline $\begin{array}{l}\text { Number of observations } \\
\chi^{2}\end{array}$ & $\begin{array}{r}3,768 \\
231.925\end{array}$ & $\begin{array}{r}3,768 \\
275.976\end{array}$ & $\begin{array}{r}3,768 \\
297.445\end{array}$ & $\begin{array}{l}2,418 \\
71.884\end{array}$ & $\begin{array}{l}2,418 \\
93.135\end{array}$ & $\begin{array}{r}2,418 \\
114.104\end{array}$ \\
\hline
\end{tabular}

Note. Standard errors are in parentheses.

$+p<0.10 ;{ }^{*} p<0.05 ;{ }^{* *} p<0.01$. 
between political connections and corporate charitable donation. In contrast to the negative effect of ascribed bureaucratic connections upon donation (main effect), the interaction between chairs' ascribed bureaucratic connections and the level of state monopoly is significantly positive, on both the likelihood $(\beta=1.785, p<$ $0.01)$ and the amount of donation $(\beta=2.763, p<$ $0.01)$. This means that the buffering effect of executives' ascribed bureaucratic connections from pressure to donate is weaker in more state-monopolized industries. So H3A is supported. The same positive interaction effect is found for the interaction term between chairs' achieved political connections and the level of state monopoly; both coefficient estimates on the likelihood $(\beta=2.242, p<0.01)$ and the amount of donation $(\beta=2.093, p<0.01)$ are significantly positive, suggesting that the binding effect of executives' achieved political connections on donation is stronger for firms in more state-monopolized industries. Thus H3B is supported.

Figure 2, panels (a) and (b), visualizes how the types of ties interact with state monopoly of industry. We put level of state monopoly on the $x$-axis and used two lines to indicate the predicted probability of donation by firms with and without political connections. As shown in Figure 2(a), firms with ascribed connections are less likely to donate in more competitive industries (i.e., they buffer), but when the level of state monopoly increases, such buffering effect becomes weaker (H3A) as the slope becomes positive $(\Delta=0.258$ with $p<0.001)$. Similarly, Figure 2(b) shows that firms with achieved political connections are more likely to donate, particularly in industries with a higher level of state monopoly, suggesting that the binding effect of achieved political connections is stronger in state-monopolized industries $(\mathrm{H} 3 \mathrm{~B})$ as the slope is positive $(\Delta=0.879$ with $p<0.001)$.

Figure 2 The Moderating Effect of State Monopoly of Industry

(a) Ascribed bureaucratic connection

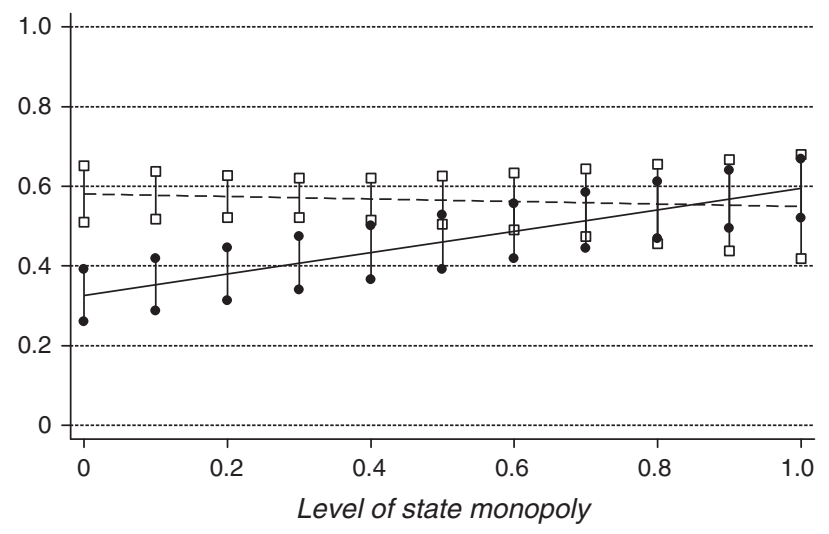

$$
\begin{aligned}
\square \longrightarrow \text { Confidence interval }----\cdot & \text { Ascribed bureaucratic } \\
& \text { connection }=0 \\
\longrightarrow \text { Confidence interval } \longrightarrow & \begin{array}{l}
\text { Ascribed bureaucratic } \\
\text { connection }=1
\end{array}
\end{aligned}
$$

Note. The figure is based on model 3 of Table 3.
Hypotheses 4A and 4B examine the moderating effects of the quality of regional market development on the relationship between political connections and corporate charitable donation. The results show that the interaction effect between chairs' (both types of) political connections and quality of regional market development (a higher score means lower quality) negatively affect both the likelihood and the amount of donation significantly. These indicate that the buffering effect of executives' ascribed bureaucratic connections against pressure to donate is stronger and the binding effect of executives' achieved political connections to donate is weaker for firms in regions with low level of market development. Hypothesis 4A and 4B are thus supported.

Figures 3(a) and 3(b) illustrate the interaction effects visually. Figure 3(a) indicates that ascribed bureaucratic connections buffer in all regions, and the effect becomes stronger when the quality of market development decreases (H4B; $\Delta=-0.937$ with $p<0.001$ ). Figure 3(b) shows that the binding effect of achieved political connection to donate is seriously weakened in regions with lower quality of market development (H4B) $(\Delta=-0.302$ with $p<0.001)$, but in regions with higher quality of market development, firms with achieved connections are more likely to donate.

Based on model 6 (Table 3), holding other things constant, we calculated the predicted donation amount of firms with political connections. Among those that have donated, firms with ascribed bureaucratic connections donate $¥ 48,260$ (US\$6,539) less, whereas those with achieved political connections donate $¥ 62,891$ (US\$8,522) more, compared to their respective counterparts. A standard deviation increase in level of state monopoly increases the amount of donation for firms with ascribed bureaucratic connections by $¥ 8,242$ (US\$1,117), and increases

(b) Achieved political connection
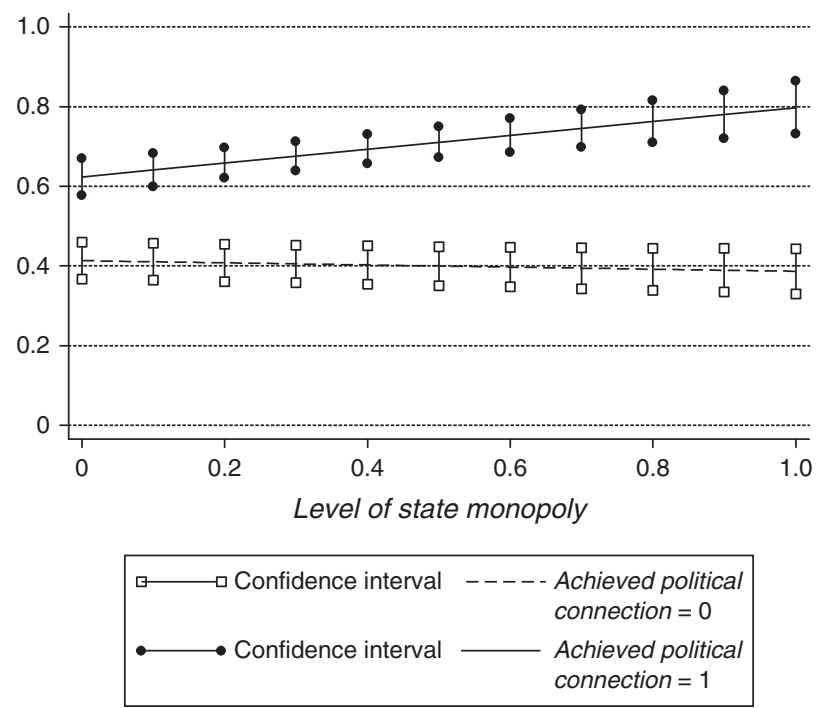
Figure 3 The Moderating Effect of Quality of Regional Market Development

(a) Ascribed bureaucratic connection
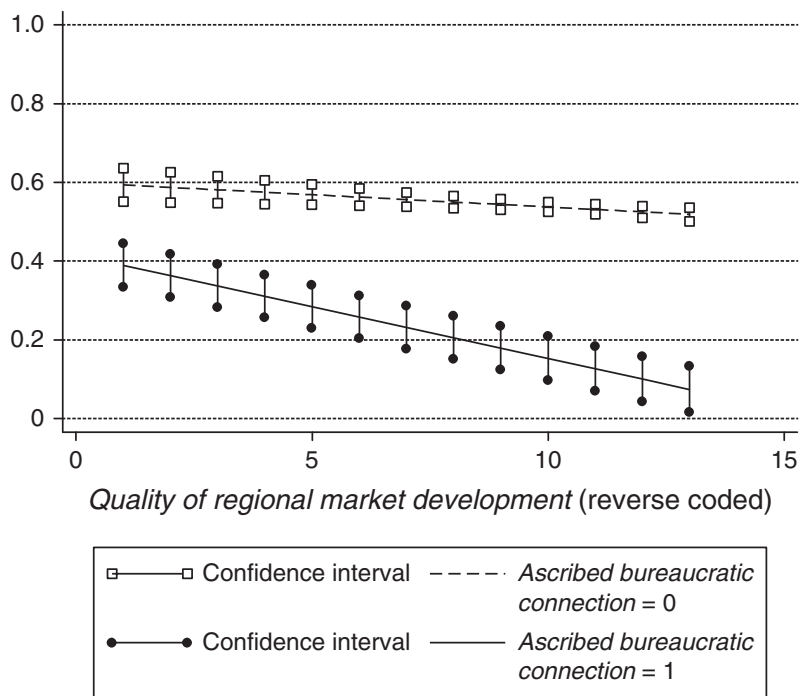

Note. The figure is based on model 3 of Table 3.

the amount of donation for firms with achieved political connections by $¥ 6,244$ (US\$846). In contrast, a standard deviation increase in quality of regional market development (i.e., less market-oriented regions) decreases the amount of donation for firms with ascribed bureaucratic connections by $¥ 3,156$ (US $\$ 428$ ), and decreases the amount of donation for firms with achieved political connections by $¥ 2,722$ (US\$369).

As for the control variables, the results show that firm size is positively associated with the likelihood of donation. Newly listed firms are more likely to donate and donate in larger amount, probably because they are more likely to comply with external pressures due to recent IPO or they are still establishing their public image. Financial performance (ROA) has a positive impact upon the likelihood of donation, which is consistent with Wang and Qian (2011). We also find evidence that firms with higher advertising intensity are less likely to donate. This result may suggest that when donation is somewhat coercive or demanded by the government, it does not function as a complement to advertising like it does in developed economies (Servaes and Tamayo 2013). Finally, the percentage of firms that donated in the same industry and the average amount of donation in the same industry are positively associated with the likelihood and amount of donation respectively, indicating an imitation effect.

\section{Further Analyses and Robustness Checks}

We also conducted a number of additional analyses to check the robustness of the results. One issue is that we cannot be fully sure of firm motivation and whether they donated voluntarily or were forced to donate. To better understand this issue, we attempt to identify "voluntary donation" by (1) the consistency of donation (b) Achieved political connection
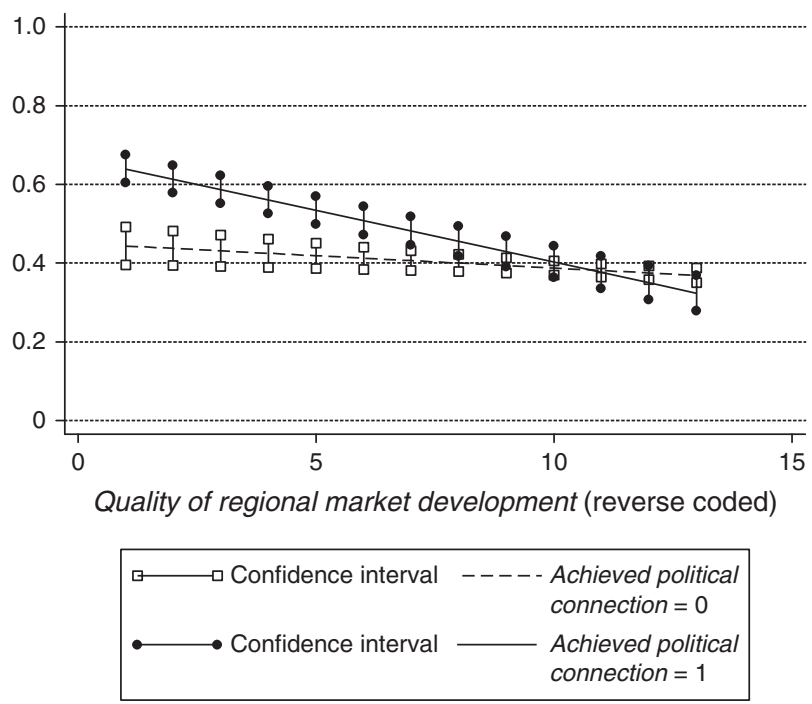

(whether a firm donated every year) and (2) whether the amount of donation was relatively large (e.g., the highest half, quartile, deciles, quintile, or above median, etc.), assuming that consistent donors and those who donate larger amounts are more likely to donate voluntarily. The results presented in Table B1 in Online Appendix B show that firms whose chairpersons have achieved political connections are more likely to donate voluntarily by this definition. Such effect is strengthened in more statemonopolized industries and weakened in regions with poorer market development.

We also conducted subsample regressions in case industrial and regional differences are associated with political connections as well as corporate charitable donations. First, we split the sample into manufacturing and nonmanufacturing industries ( $\mathrm{Li}$ and Tang 2010). Second, we divide our sample into three economic regions: east, middle, and west (Bhalla et al. 2003). The split sample results across these different industries and regions are reported in the last five columns of Table B1 in Online Appendix B and are consistent with our main results.

We further explored the impact of the political rank of the chairperson upon donation. We coded the political rank of the ascribed bureaucratic connection from 1 (below the township level) to 9 (the provincial/ ministerial level), and those without such connections are coded 0 . The results (presented in Table B2 in Online Appendix B) indicate that the ascribed bureaucratic connection with consideration of rank has a stronger buffering effect; i.e., the higher the political rank, the stronger the buffering effect. This suggests that former government officials with higher political rank are more powerful in protecting their firms' interests by defying rent expropriation. 
Last, as an alternative to address the endogeneity issue, we also use the instrumental variable approach and found that the results are consistent with those by propensity score matching. Details of our selection of instrumental variables and the corresponding results are presented in Table C1 in Online Appendix C.

\section{Discussion and Conclusions}

Our research addresses an important theoretical puzzle concerning the effect of political connections on firm behavior; i.e., do they buffer the firm from or bind the firm to the government? We distinguish two types of political connections - ascribed bureaucratic connections and achieved political connections-and reveal their different functions. We further show that whether political connections buffer the firm from or bind the firm to the government is contingent upon the firm's institutional context, including the level of state monopoly of industry and the quality of regional market development.

Below, we discuss our theoretical contributions to research on political connections, the institutional contingencies of political connections, and, more generally, the relationship between corporate social responsibility and corporate political activities.

\section{Beyond the Double-Edged Function of Political Connections}

Our findings corroborate prior conceptualizations of the double-edged function of political connections, but go beyond this conceptualization by showing that it is not that each specific tie can have opposing functions, but that there are systematic differences between types of ties and institutional contingencies upon which ties have a buffering or binding function. As noted, we found that ascribed bureaucratic connections are more likely to serve as a buffer; in contrast, achieved political connections are more likely to create binding effects. Such evidence indicates that the two types of political connections mean different things, indicate different relationships (with the government), and function differently. In general, ascribed bureaucratic connections provide power and leverage to buffer against external impositions, while achieved political connections, beyond their instrumental value to protect firms from administrative harassment, bind firms to meet government and social expectations. In addition, successful entrepreneurs' prosocial tendencies and legitimacy-seeking behavior ( $\mathrm{Li}$ and Liang 2015), together with government's efforts to incorporate successful entrepreneurs to the political system (Dickson 2003), also strengthen such a binding effect.

More importantly, our study suggests a bidirectional influence in the relationship between business and government, embodied by political connections. Political connections not only provide channels for business to gain benefits and protect its own interest, but also create channels/avenues for government to influence/penetrate business. As Shleifer and Vishny (1994) emphasize, while firms might get benefits/rents from political connections, politicians themselves will extract at least some of the rents generated by the connections. To gain and maintain political appointments, business executives must take the government's concern into consideration, e.g., actively share responsibilities with the government and take the lead in following the government's calls. As a result, firms seeking political embeddedness might also risk losing certain autonomy and resources.

It is important to emphasize that this conceptualization of buffering versus binding effects of political connections is not just specific to the Chinese context. As the recent review by Mellahi et al. (2016) indicates, buffering is common around the world. For instance, Claessens et al. (2008) argues that political connections shield Brazilian firms from government demands, and similar results are found in the study by Barth et al. (2008) across 150 countries. On the other hand, binding effects has also been found in a wide range of contexts (Choi and Thum 2009, Robinson and Verdier 2013). For example, in France, politically connected firms are more active in reducing the unemployment rate in exchange for benefits such as tax breaks and subsidies (Bertrand et al. 2007).

\section{Institutional Contingency of Political Connections}

We further find that the function of political connections is contingent upon institutional contexts, and different institutions influence organizations differently (Sun et al. 2012). These institutional factors affect the extent to which a firm depends on the state or market to succeed, which in turn determines the necessity (and value) of using corporate giving to maintain political connections, as well as the necessity and the feasibility of defying government demands. In other words, institutional factors shape the extent to which a firm should consider the government as an important stakeholder in their decision making.

A unique aspect of our study is that we document the different moderating effects of industry and region. While prior research has postulated important institutional effects stemming either from industry (e.g., DiMaggio and Powell 1983) or region (e.g., Marquis and Battilana 2009), there are few studies contrasting the two. Analyzing and comparing these two institutions is thus both theoretically and practically important since virtually all firms simultaneously face institutional pressures from both industry and region. Different political systems and institutional arrangements may create different institutional pressures from region and industry, and/or different combinations of the two in terms of government regulation. As we show, in more statemonopolized industries, both types of political connections positively influence donation, whereas in more 
competitive industries, both types of political connections are more likely to serve as buffers. In contrast, the moderating role of region is strikingly different: in less market-oriented regions, both types of political connections work as buffers; in more market-oriented regions, achieved political connections significantly bind firms to donate (Figure 3(b)), while ascribed bureaucratic connections still buffer firms from the donation pressure (Figure 3(a)).

Such different impacts of industry and region largely result from the differing nature of their associated institutional pressures. As we discussed previously, the task environment of industry generates stronger and consistent resource dependence of the focal firm upon the government, while the institutional environment of region generates fragmented, inconsistent, and relatively weaker resource dependence of the focal firm on the government. Meanwhile, both industry and region embody variation of state presence (i.e., state-monopolized versus competitive industries; less market-oriented regions versus more market-oriented regions). Based on our conceptualization of these two different dimensions, as well as our empirical findings, we can tentatively classify three institutional conditions under which political connections function differently, thus providing a general framework to encompass both industrial and regional effects.

First, in situations with strong and consistent resource dependence of firms upon the government (such as statemonopolized industries), organizations must proactively pursue competitive advantage through cultivating and maintaining political connections; meanwhile, they cannot afford the cost of defying government demands. Under such conditions, political connections serve as conduit or bridge for further political advantages, which is why we observe that both types of political connections facilitate donation.

Second, in situations with moderate resource dependence of corporations upon the state, such as in competitive industries, or situations with multiple and fragmented environment constituents (Greenwood et al. 2011), such as less market-oriented regions, it is both necessary and feasible for organizations to resist government demands to protect firm interests. In these situations, political connections thus serve as a buffer, helping firms protect their interests from rent expropriation (Xin and Pearce 1996).

Last, in situations where firms' dependence upon the state is weak and the market plays a more important role in shaping competition, i.e., in more market-oriented regions, executives with achieved political connections may be more aware of using donation as a marketing tool or have more latitude to express their intrinsic interests, for example, donating out of a high CSR awareness or prosocial duty (Li and Liang 2015). In this context the entrepreneurs/firms may behave like what is expected in the West, where discretionary philanthropy prevails (Galaskiewicz 1997). Future research can investigate whether this is the case and whether this will be the trend with the progress of China's market transition.

Our conceptualization of different institutional conditions thus enables us to better understand the subtlety of the shifting function of certain political connections and how firms use their connections strategically. For example, ascribed bureaucratic connections mainly buffer, but in state-monopolized industries, they actually facilitate donation, while achieved political connections in general create a binding effect, but such connections function more as buffer in less market-oriented regions to protect firms from rent expropriation. This once again demonstrates the contingent nature of political connections as well as the institutional bases of firm strategy (Sun et al. 2012).

\section{Relationship Between CSR and CPA}

Considering the overlap between the social and political aspects of corporate strategies, scholars have noticed that business organizations tend to integrate or align their CSR with CPA to pursue competitive advantage (Baron and Diermeier 2007, Werner 2015). But the relationship between the two is less clear (Delmas et al. 2016, Mellahi et al. 2016, Sun et al. 2012). Some studies suggest that the two activities complement each other, e.g., CSR facilitates corporate political access (McWilliams et al. 2002, Werner 2015). Others suggest that given that both CSR and CPA are not cost-free, the two nonmarket strategies can also serve as substitutes (Wang and Qian 2011); that is, if firms consider one strategy to be effective in achieving/protecting their interests, why would they bother to spend more resources on the other?

Our study contributes to this literature by differentiating types of political connections and institutional conditions. We show that ascribed bureaucratic connections serve more as a substitute to donation, while achieved political connections are more likely to serve as a complement to donation. In addition, whether CSR and CPA complement or substitute each other is largely a result of firms' level of dependence on the government: in situations where firms highly depend on the government for survival and success (such as in state-monopolized industries), charitable donations serve as a complement to maintain/strengthen political connections, whereas in situations where firms depend more on the market for success, political connections substitute charitable donations. In sum, donations actually serve as another tool in a firm's strategic and political toolbox, with firms utilizing it depending on the relative strengths and weaknesses of their other political resources as well as institutional conditions.

\section{Limitations and Future Research}

Our study differentiates the different natures/functions of political connections with an application to corporate 
charitable donations. Future research can investigate and extend our findings in a number of directions. First, future research can examine other types of political connections and decipher their functions, such as political connections cultivated through political contributions, intimate relationships, and family ties (Faccio 2006). Future research can also examine the function of expired political appointments-after executives' tenures of political appointment are over. Second, while this research chooses charitable donation as a research phenomenon to examine the differing impacts of political connections, future research can investigate other organizational behaviors on which political connections may have varying influence. Third, research on the impact of political connections on corporate charitable donations or other CSR behaviors (or the relationship between CPA and CSR) can extend our findings to contexts beyond China. Finally, fieldwork and executive interviews are needed to better understand the different natures of political connections and their impact on firms' behavior, as well as the underlying motives of charitable donation.

\section{Conclusions}

Research on political connections typically focuses on either their benefits for firms (i.e., buffering them from the government) or their binding effect for firms to meet government expectations. Yet, research has not yet clarified the puzzle of what types of political connections are more likely to function as buffers and what types of political connections are more likely to bind, and the institutional conditions that affect these relationships. Our study addresses this puzzle by differentiating two types of political connections and identifying two institutional contingencies. Our study thus goes beyond prior conceptualizations of political connections as a doubleedged sword and shows that political connections actually provide two distinct influences: for government to influence corporations and for firms to influence the government. More importantly, we show that the function of political connections is not fixed; on the contrary, it varies with institutional conditions. Both government and business can be strategic and instrumental in exploiting such interorganizational linkages, and both face ongoing challenges to manage the tension between cooperation and conflict.

\section{Supplemental Material}

Supplemental material to this paper is available at http://dx.doi .org/10.1287/orsc.2016.1084.

\section{Acknowledgments}

The authors are grateful to senior editor Brayden King, two anonymous reviewers, Anne Tsui, Joseph Galaskiewicz, Chao Chen, Lu Zheng, and Dali Ma for their helpful comments. This research was supported by grants from the Chinese National Natural Science Foundation [Grant 71572003] and Guanghua Leadership Institute [Grant 10-01].

\section{Endnotes}

${ }^{1}$ More than half of all donations go to education, poverty alleviation, or disaster relief, which are considered government duties.

${ }^{2}$ See, for example, Zhang 2012.

${ }^{3}$ Though "forced donation" may be more pronounced in China, the political nature of CSR activities like philanthropy is not China unique; that is, CSR may be firms' response to pressures generated not just by NGOs and social activists, but also by the government (Baron et al. 2011).

${ }^{4}$ For the delegates to PC or CPPCC at city level or above, the term is five years. For sub-city level, i.e., county or township level, the term is three years.

${ }^{5}$ As Chinese tradition does not encourage lawsuits and the legal apparatus is not effective, individuals/firms develop many informal ways to solve conflict (Fei 1992).

${ }^{6}$ To maintain consistency on estimation for the second dependent variable, the amount of donation, which requires the twostep Heckman selection model, we utilized probit models with random effects for the likelihood of donation as the first step. ${ }^{7} \mathrm{We}$ obtained similar results by excluding firms with both types of political connections before implementing PSM and obtained similar results as those reported.

${ }^{8}$ We employed nearest-neighbor matching without replacement and a set caliper ( 0.25 standard deviation) to determine which propensity scores were sufficiently high for observations in the control group to be included in the matched sample. While we followed the common rule of thumb to set the caliper to 0.25 standard deviation (Choi et al. 2014), the results stay similar if we set the caliper to 0.20 or 0.15 standard deviation.

\section{References}

Agrawal A, Knoeber CR (2001) Do some outside directors play a political role? J. Law Econom. 44(1):179-198.

Baron DP (1995) Integrated strategy: Market and nonmarket components. California Management Rev. 37(2):47-65.

Baron DP, Diermeier, D (2007) Introduction to the special issue on nonmarket strategy and social responsibility. J. Econom. Management Strategy 16(3):539-545.

Baron DP, Harjoto MA, Jo H (2011) The economics and politics of corporate social performance. Bus. Politics 13(2):1.

Barth JR, Caprio G, Levine R (2008) Rethinking Bank Regulation: Till Angels Govern (Cambridge University Press, Cambridge, UK).

Bertrand M, Schoar A, Thesmar D (2007) Banking deregulation and industry structure: Evidence from the French banking reforms of 1985. J. Finance 62(2):597-628.

Bhalla A, Yao S, Zhang Z (2003) Regional economic performance in China. Econom. Transition 11(1):25-39.

Boddewyn JJ, Brewer TL (1994) International-business political behavior: New theoretical directions. Acad. Management Rev. 19(1):119-143.

Boisot M, Child J (1996) From fiefs to clans and network capitalism: Explaining China's emerging economic order. Admin. Sci. Quart. 41(4):600-628.

Boubakri N, Cosset JC, Saffar W (2008) Political connections of newly privatized firms. J. Corporate Finance 14(5):654-673.

Breusch TS, Pagan AR (1979) A simple test for heteroscedasticity and random coefficient variation. Econometrica 47(5):1287-1294.

Brown W, Helland E, Kiholm-Smith J (2006) Corporate philanthropic practices. J. Corporate Finance 12(5):855-877. 
Caprio L, Croci E (2008) The determinants of the voting premium in Italy: The evidence from 1974 to 2003. J. Bank Finance 32(11):2433-2443.

Chen CJ, Li Z, Su X, Sun Z (2011) Rent-seeking incentives, corporate political connections, and the control structure of private firms: Chinese evidence. J. Corporate Finance 17(2):229-243.

Chin MK, Hambrick DC, Treviño LK (2013) Political ideologies of CEOs: The influence of executives' values on corporate social responsibility. Admin. Sci. Quart. 58(2):197-232.

China Charity Information Centre (2007-2014) China Charity report. Accessed April 10, 2016, http://www.zmcs.org.cn/.

Choi JP, Thum M (2009) The economics of politically-connected firms. Internat. Tax Public Finance 16(5):605-620.

Choi SJ, Jia N, Lu J (2014) The structure of political institutions and effectiveness of corporate political lobbying. Organ. Sci. 26(1):158-179.

Claessens S, Feijen E, Laeven L (2008) Political connections and preferential access to finance: The role of campaign contributions. J. Financial Econom. 88(3):554-580.

Clemens ES, Guthrie D (2010) Politics and Partnerships: The Role of Voluntary Associations in America's Political Past and Present (University of Chicago Press, Chicago).

Correia MM (2014) Political connections and SEC enforcement. J. Accounting Econom. 57(2):241-262.

Davis GF, Greve HR (1997) Corporate elite networks and governance changes in the 1980s. Amer. J. Sociol. 103(1):1-37.

Davies H, Walters P (2004) Emergent patterns of strategy, environment and performance in a transition economy. Strategic Management J. 25(4):347-364.

Dehejia RH, Wahba S (2002) Propensity score-matching methods for nonexperimental causal studies. Rev. Econom. Statist. 84(1): 151-161.

Delmas MA, Lim J, Nairn-Birch N (2016) Corporate environmental performance and lobbying. Acad. Management Discoveries 2(2):175-197.

Dickson B (2003) Red Capitalists in China: The Party, Private Entrepreneurs, and Prospects for Political Change (Cambridge University Press, Cambridge, UK).

Dieleman M, Boddewyn JJ (2012) Using organization structure to buffer political ties in emerging markets: A case study. Organ. Stud. 33(1):71-95.

DiMaggio P, Powell WW (1983) The iron cage revisited: Collective rationality and institutional isomorphism in organizational fields. Amer. Sociol. Rev. 48(2):147-160.

Eaton S (2013) Political economy of the advancing state: The case of China's airlines reform. China J. 69(1):1324-9347.

Faccio M (2006) Politically connected firms. Amer. Econom. Rev. 96(1):369-386

Fan G, Wang X, Zhu H (2011) NERI Index of Marketization of China's Provinces (Economic Science Press, Beijing)

Fan JP, Wong TJ, Zhang T (2007) Politically connected CEOs, corporate governance, and post-IPO performance of China's newly partially privatized firms. J. Financial Econom. 84(2):330-357.

Fei X (1992) From the Soil: The Foundation of Chinese Society (University of California Press, Berkeley)

Firth M, Rui OM, Wu W (2011) The effects of political connections and state ownership on corporate litigation in China. J. Law Econom. 54(3):573-607.

Fligstein N, Zhang J (2011) A new agenda for research on the trajectory of Chinese capitalism. Management Organ. Rev. 7(1):39-62.

Foster K (2001) Associations in the embrace of an authoritative state: State domination of society? Stud. Comparative Internat. Development 35(4):84-109.
Galaskiewicz J (1997) An urban grants economy revisited: Corporate charitable contributions in the twin cities, 1979-81, 1987-89. Admin. Sci. Quart. 42(3):445-471.

Gallagher KS (2006) Limits to leapfrogging in energy technologies? Evidence from the Chinese automobile industry. Energy Policy 34(4):383-394.

Ginsburg T, Moustafa T (2008) Rule by Law: The Politics of Courts in Authoritarian Regimes (Cambridge University Press, Cambridge, UK).

Grant RM, Jammine AP, Thomas H (1988) Diversity, diversification, and profitability among British manufacturing companies, 19721984. Acad. Management J. 31(4):771-801.

Greenwood R, Raynard M, Kodeih F, Micelotta ER, Lounsbury M (2011) Institutional complexity and organizational responses. Acad. Management Ann. 5(1):317-371.

Guthrie D, McQuarrie M (2008). Providing for the public good: Corporate-community relations in the era of the receding welfare state. City Commun. 7(2):113-139.

Hambrick DC, Mason PA (1984) Upper echelons: The organization as a reflection of its top managers. Acad. Management Rev. 9(2): 193-206.

Hausman JA (1978) Specification tests in econometrics. Econometrica 46(6):1251-1271.

Haveman HA, Jia N, Shi J, Wang Y (2016) The dynamics of political embeddedness in China. Admin. Sci. Quart., ePub ahead of print June 23, http://dx.doi.org/10.1177/0001839216657311.

Hillman AJ (2005) Politicians on the board of directors: Do connections affect the bottom line? J. Management 31(3):464-481.

Hillman AJ, Keim GD, Schuler D (2004) Corporate political activity: A review and research agenda. J. Management 30(6):837-857.

Hillman AJ, Zardkoohi A, Bierman L (1999) Corporate political strategies and firm performance: Indications of firm-specific benefits from personal service in the US government. Strategic Management J. 20(1):67-81.

Hoskisson RE, Eden L, Lau CM, Wright M (2000) Strategy in emerging economies. Acad. Management J. 43(3):249-267.

Jin Y (2005) Institutional interpretation of wage inequality across industries. Statist. Res. 22(4):10-15.

Kostka G, Zhou J (2013) Government-business alliances in state capitalist economies: Evidence from low-income markets in China. Bus. Politics 15(2):245-274.

Kozhikode RK, Li JT (2012) Political pluralism, public policies, and organizational choices: Banking branch expansion in India, 1948-2003. Acad. Management J. 55(2):339-359.

Lancaster T (2000) The incidental parameter problem since 1948. J. Econometrics 95(2):391-413.

Lester RH, Hillman A, Zardkoohi A, Cannella AA (2008) Former government officials as outside directors: The role of human and social capital. Acad. Management J. 51(5):999-1013.

Li H, Zhang Y (2007) The role of managers' political networking and functional experience in new venture performance: Evidence from China's transition economy. Strategic Management J. 28(8):791-804.

Li J, Tang Y (2010) CEO hubris and firm risk taking in China: The moderating role of managerial discretion. Acad. Management $J$. 53(1):45-68.

Li X, Liang X (2015) A Confucian social model of political appointments among Chinese private-entrepreneurs. Acad. Management J. 58(2):592-617.

Li JJ, Poppo L, Zhou KZ (2008) Do managerial ties in China always produce value? Competition, uncertainty, and domestic vs. foreign firms. Strategic Management J. 29(4):383-400.

Li H, Meng L, Wang Q, Zhou LA (2008) Political connections, financing and firm performance: Evidence from Chinese private firms. J. Development Econom. 87(2):283-299. 
Linton R (1936) The Study of Man: An Introduction (AppletonCentury, Oxford, UK).

Ma D, Parish W (2006) Tocquevillian moments: Charitable contributions by Chinese private entrepreneurs. Social Forces 85(2): 943-964.

Ma X, Tong TW, Fitza M (2013) How much does subnational region matter to foreign subsidiary performance? Evidence from Fortune global 500 corporations' investment in China. J. Internat. Bus. Stud. 44(1):66-87.

Marquis C, Battilana J (2009) Acting globally but thinking locally? The enduring influence of local communities on organizations. Res. Organ. Behav. 29(December):283-302.

Marquis C, Qian C (2014) Corporate social responsibility reporting in China: Symbol or substance? Organ. Sci. 25(1):127-148.

Marquis C, Raynard M (2015) Institutional strategies in emerging markets. Acad. Management Ann. 9(1):291-335.

McGinnis A, Pellegrin J, Shum Y, Teo J, Wu J (2009) The Sichuan earthquake and the changing landscape of CSR in China. Knowledge@Wharton (April 20), http://knowledge.wharton.upenn.edu/ article/the-sichuan-earthquake-and-the-changing-landscape-of-csr -in-china/.

McWilliams A, Van Fleet DD, Cory KD (2002) Raising rivals' costs through political strategy: An extension of resource-based theory. J. Management Stud. 39(5):707-724.

Mellahi K, Frynas JG, Sun P, Siegel D (2016) A review of the nonmarket strategy literature: Toward a multi-theoretical integration. J. Management 42(1):143-173.

Navarro P (1988) Why do corporations give to charity? J. Bus. 61(1):65-93.

Oliver C (1991) Strategic responses to institutional processes. Acad. Management Rev. 16(1):145-179.

Ortega DL, Wang HH, Olynk NJ, Wu L, Bai J (2011) Chinese consumers' demand for food safety attributes: A push for government and industry regulations. Amer. J. Agricultural Econom. 94(2):489-495.

Palazzo G, Richter U (2005) CSR business as usual? The case of the tobacco industry. J. Bus. Ethics 61(4):387-401.

Peng MW, Luo Y (2000) Managerial ties and firm performance in a transition economy: The nature of a micro-macro link. Acad. Management J. 43(3):486-501.

Pfeffer J, Salancik G (1978) The External Control of Organizations (Harper and Row, New York).

Robinson JA, Verdier T (2013) The political economy of clientelism. Scandinavian J. Econom. 115(2):260-291.

Rosenbaum PR, Rubin DB (1983) The central role of the propensity score in observational studies for causal effects. Biometrika 70(1):41-55.

Sauerwald S, Lin ZJ, Peng MW (2016) Board social capital and excess CEO returns. Strategic Management J. 37(3):498-520.

Schuler DA, Rehbein K, Cramer RD (2002) Pursuing strategic advantage through political means: A multivariate approach. Acad. Management J. 45(4):659-672.

Servaes H, Tamayo A (2013) The impact of corporate social responsibility on firm value: The role of customer awareness. Management Sci. 59(5):1045-1061.

Shi W, Markóczy L, Stan CV (2014) The continuing importance of political ties in China. Acad. Management Perspect. 28(1):57-75.

Shleifer A, Vishny R (1994) Politicians and firms. Quart. J. Econom. 109(4):995-1025.

Song L, Yang J, Zhang Y (2011) State-owned enterprises' outward investment and the structural reform in China. China World Econom. 19(4):38-53.
Stark R (2007) Sociology, 10th ed. (Cengage Learning, Boston).

Sun P, Mellahi K, Wright M. (2012) The value of corporate political ties. Acad. Management Perspect. 26(3):68-82.

Sun P, Mellahi K, Wright M, Xu H (2015) Political tie heterogeneity and the impact of adverse shocks on firm value. J. Management Stud. 52(8):1036-1063.

Swanson DL (1999) Toward an integrative theory of business and society: A research strategy for corporate social performance. Acad. Management Rev. 24(3):506-521.

Thomas AS, Litschert RJ, Ramaswamy K (1991) The performance impact of strategy-manager coalignment: An empirical examination. Strategic Management J. 12(7):509-522.

Thompson JD (1967) Organizations in Action: Social Science Bases of Administrative Theory (McGraw-Hill, New York).

Wang F (2011) The fact of philanthropic donation in Shenmu. 21st Century Business Herald (April 21), http://finance.sina.com .cn/roll/20110426/00399748570.shtml.

Wang H, Qian C (2011) Corporate philanthropy and corporate financial performance: The roles of stakeholder responses and political access. Acad. Management J. 54(6):1159-1181.

Werner $T$ (2015) Gaining access by doing good: The effect of sociopolitical reputation on firm participation in public policymaking. Management Sci. 61(8):1989-2011.

West LA, Wong CP (1995) Fiscal decentralization and growing regional disparities in rural China: Some evidence in the provision of social services. Oxford Rev. Econom. Policy 11(4):70-84.

Wu W, Wu C, Zhou C, Wu J (2012) Political connections, tax benefits and firm performance: Evidence from China. J. Accounting Public Policy 31(3):277-300.

Xin KR, Pearce JL (1996) Guanxi: Connections as substitutes for formal institutional support. Acad. Management J. 39(6): $1641-1658$.

Yu F, Yu X (2011) Corporate lobbying and fraud detection. J. Financial Quant. Anal. 46(6):1865-1891.

Zhang W (2012) Coercive donation is a hurt to philanthropy. People's Daily (May 16), http://society.people.com.cn/GB/1063/17896781 .html.

Zheng W, Singh K, Mitchell W (2015) Buffering and enabling: The impact of interlocking political ties on firm survival and sales growth. Strategic Management J. 36(11):1615-1636.

Zhou KZ, Poppo L (2010) Exchange hazards, relational reliability, and contracts in China: The contingent role of legal enforceability. J. Internat. Bus. Stud. 41(5):861-881.

Jianjun Zhang is associate professor of organization and strategic management at Guanghua School of Management, Peking University. He received his $\mathrm{PhD}$ from the University of California, Berkeley. His research interests include corporate social responsibility, corporate political activity, and top management teams.

Christopher Marquis is the Samuel C. Johnson Professor in Sustainable Global Enterprise at the Johnson Graduate School of Management, Cornell University. He received his $\mathrm{PhD}$ from the University of Michigan. He studies the environmental sustainability and shared value strategies of global corporations, with a particular emphasis on firms in China.

Kunyuan Qiao is a $\mathrm{PhD}$ student of management at the Mays Business School, Texas A\&M University. He received his MA in economics from Pennsylvania State University and Peking University, and BA in economics and BS in statistics from Peking University. His current research interests include top management teams, strategic leadership, and corporate governance. 